\title{
Diabetes and Clinical Research
}

\section{Biocompatible Scaffolds: An Effective Means for Improving Islet Cells Viability and Function}

\author{
Reza B Jalili',2* and Aziz Ghahary ${ }^{1,2}$ \\ ${ }^{1}$ Burn and Wound Healing Research Group, Department of Surgery, University of British Columbia, \\ Vancouver, BC, Canada \\ ${ }^{2}$ International Collaboration on Repair Discoveries (ICORD), University of British Columbia, Vancouver, \\ $B C$, Canada
}

*Corresponding author: Reza B Jalili, MD, PhD, Assistant Professor, Burn and Wound Healing Research Group, International Collaboration on Repair Discoveries, Department of Surgery, University of British Columbia, $818 \mathrm{~W} 10^{\text {th }}$ Ave, Vancouver, BC, V5Z1M9, Canada, E-mail: rjalili@mail.ubc.ca

\begin{abstract}
Islets of Langerhans are endocrine units of the pancreas. Local microenvironment of islets includes their immediate extracellular matrix and other molecules that surround islets within the exocrine pancreas. Transplantation of pancreatic islets, which is a promising method for treatment of type 1 diabetes, encounters several challenges including premature loss of grafted islets. The native islet extracellular matrix is disrupted during the process of enzymatic digestion of pancreas, which is required for isolation of islet from exocrine tissue. The lack of extracellular matrix then leads to a significant impairment of islet cell survival and function. This review outlines the significance of extracellular matrix in maintaining islet viability and integrity and summarizes the current body of knowledge regarding the role of different types of biocompatible extracellular matrices in improving islet cell viability and functionality in both in vitro and in vivo.
\end{abstract}

\section{Introduction}

Islets of Langerhans constitute about one to two percent of the volume of pancreas and are responsible for secretion of an array of metabolic hormones including insulin and glucagon [1]. Over the past couple of decades, transplantation of pancreatic islets has been advanced as a promising alternative to insulin replacement therapy for management type 1 diabetes mellitus [2]. Islet transplantation restores endogenous insulin and glucagon production and reinstates glucose homeostasis $[3,4]$. This therapeutic procedure, however, faces several challenges including shortage of islet sources and poor engraftment of transplanted islets [5]. Although in the first year post-transplantation up to $80 \%$ of islet graft recipients enjoy their insulin independence, graft function declines to less than 50\% by five years after transplantation even with vigorous anti-rejection regimens [6]. This graft survival statistics highlights the significance of non-immunological causes of islet graft loss. Additionally, more than one donor (up to three) is usually required per islet graft recipient to achieve sustained insulin independence [7]. In contrast to the islet transplantation, usually only one donor pancreas is sufficient to completely correct the metabolic abnormalities of diabetes with whole-organ pancreas transplantation [8]. As such, in the view of the limited supply of donor organs, the need for greater number of donor pancreas to achieve insulin independence per islet graft recipient is a major limitation for islet transplantation.

Damage to islets during the isolation procedure or loss of viable islets shortly after transplantation are possible explanations for non-immunological islet graft. Indeed, up to $70 \%$ of the transplanted islets may be damaged in the early post-transplant period even in the absence of immune attack $[9,10]$. This premature islet loss then leads to the requirement of multiple donors per each islet graft recipient.

Susceptibility to microenvironment disruption with subsequent functional impairment and islet cell apoptosis can result in loss of graft function [11]. Islet isolation process involves enzymatic digestion of pancreatic tissue, which inevitably results in the loss of peripheral

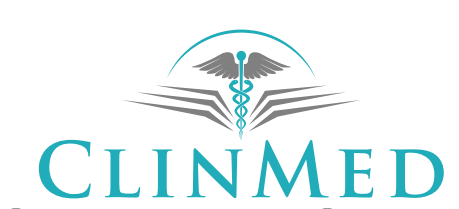

INTERNATIONAL LIBRARY
Citation: Jalili RB, Ghahary A (2017) Biocompatible Scaffolds: An Effective Means for Improving Islet Cells Viability and Function. Int J Diabetes Clin Res 4:076. doi.org/10.23937/2377-3634/1410076 Received: September 07, 2017: Accepted: November 15, 2017: Published: November 17, 2017 Copyright: (c) 2017 Jalili RB, et al. This is an open-access article distributed under the terms of the Creative Commons Attribution License, which permits unrestricted use, distribution, and reproduction in any medium, provided the original author and source are credited. 
Table 1: Major islet ECM components and their corresponding receptors.

\begin{tabular}{|l|l|l|}
\hline ECM protein & Location and Function & Receptors on islet cells \\
\hline Type I collagen & $\begin{array}{l}\text { Peri- and intra-islet ECM, provides tensile strength, structural integrity, } \\
\text { and survival signalling. }\end{array}$ & $\alpha_{v} \beta_{3}, \alpha_{2} \beta_{1}, D D R 2$ \\
\hline Type IV collagen & $\begin{array}{l}\text { Basement membrane, provides microstructural integrity and cell } \\
\text { stimulation, attaches to other basement membrane components. }\end{array}$ & $\alpha_{1} \beta_{1}$, DDR1 \\
\hline Fibronectin & $\begin{array}{l}\text { Basement membrane, arranged in a 3D fibrillar mesh similar to } \\
\text { collagen, plays import roles in cell adhesion and development. }\end{array}$ & $\alpha_{v} \beta_{1}, \alpha_{v} \beta_{3}, \alpha_{5} \beta_{1}$ \\
\hline Laminin & $\begin{array}{l}\text { Basement membrane, glycoprotein with trimeric structure, important } \\
\text { for cell binding, migration, and differentiation. }\end{array}$ & $\alpha_{1} \beta_{1}, \alpha_{3} \beta_{1}, \alpha_{5} \beta_{1}, \alpha_{6} \beta_{1}$ \\
\hline
\end{tabular}

basement membrane and Extracellular Matrix (ECM) surrounding the islets. These components are essential for islet integrity and damage to the islet native ECM triggers functional impairment of islets and eventual islet cell apoptosis [12-14]. In this view, reestablishment of the interactions between islet cells and the elements of their local microenvironment may preserve islet cell viability and function and eventually lead to improvement of the outcome of islet cells replacement therapies. To this end, an array of strategies aiming at protecting islet cells from early loss has been suggested to improve long-term islet graft function. This review will focus on some of these strategies particularly those that use Three-Dimensional (3D) biocompatible scaffolds to protect islets and improve their long-term viability and function.

\section{Functional structure and composition of pancreatic islet ECM}

Pancreatic islets are cell clusters that are composed of variety of cell types. The majority of islet cells are $\beta$ cells, which produce insulin that lowers blood glucose. $\alpha$ cells are the second most abundant cells within islets and secrete glucagon, which through glycogen breakdown increases blood glucose. These two types of cells comprise more that $90 \%$ of islet cells. Other less abundant islet cells include $\delta$-cells, $\varepsilon$-cells and PP-cells, which secrete other hormones and peptides [15]. These cells, alongside with capillaries and some stromal cells are organized within a spherical microarchitecture which is glued together and surrounded by a complex ECM.

ECM, in general, is composed of multiple proteins and glycoproteins that form a complex scaffold around cells. ECM plays an essential role in supporting cells both physically via structural proteins and biologically via integrins and other cell adhesion molecules [16]. ECM proteins mainly include different types of collagens, fibronectins, laminins, tenascins, elastin, and glycosaminoglycans [17]. Collagen is the most abundant ECM protein and contains triple-helix domains [18]. Twentyeight different types of collagen have been identified in vertebrates with types I to $\mathrm{V}$ to be the most common ones [19]. Collagens provide tensile strength and contribute in cell adhesion and migration. Islet ECM is mainly composed of type I and IV collagens. These collagens play an important role in supporting pancreatic islets. Fibronectins and laminins are also important compon- ents of islet ECM [12]. Fibronectins and laminins mainly connect cells to the underlying matrix and play key roles in cell adhesion and signalling. This ECM mediated signalling controls many cellular functions including differentiation, survival, and migration [20]. In particular, Islet cell-ECM crosstalk provides important survival and functional signals and maintains islet cell differentiation, viability, morphology, and function (e.g. insulin secretion) [21-24].

The crosstalk between islet cells and ECM is generally mediated by a group of cell surface receptors known as integrins, which trigger many different intracellular signalling pathways [25]. Each component of the islet ECM has selective affinity to different integrins. For instance, collagen I mainly binds to $\alpha_{v} \beta_{3}$ and $\alpha_{2} \beta_{1}$ integrins while collagen IV preferentially binds to $\alpha_{1} \beta_{1}[26,27]$. Discoidin Domain Receptors (DDRs) are another family of cell surface receptors that can bind to ECM proteins. DDRs are a group of receptor tyrosine kinases that their activation can trigger a wide array of cellular responses including differentiation, adhesion, proliferation, and survival [28]. Studies have shown that Collagen I mainly activates DDR2 while DDR1 is more responsive to collagen IV $[29,30]$. Main Islet ECM proteins and their corresponding islet cell surface receptors are summarized in Table 1.

As noted above, interaction of islets with their ECM provides important survival and functional signals [3133]. As such, when this interaction is disrupted because of enzymatic digestion of the ECM during the islet isolation process, islet cell viability and function is jeopardized. This phenomenon is known as matrix signaling mediated cell death or anoikis [34,35]. Indeed, it has been shown that anoikis after islet isolation significantly limit functional and viable islet mass [36,37].

\section{Models for reinstatement of islet-ECM interaction}

To address the problem of premature cell death and malfunction in ECM-deprived islets, many groups have tried several types of natural and synthetic scaffolds to re-establish vital islet-ECM crosstalk. These strategies mainly include entrapment of islets within various types of extracellular matrices. Entrapment of islets within an ECM generally results in improvement of islet cell survival and enhances glucose stimulated insulin secretory capacity. For instance, Weber, et al. showed that $\beta$-cell survival was significantly improved in hydrogels 
containing collagen type I, collagen type IV, fibrinogen, fibronectin, laminin, and vitronectin. Glucose stimulated insulin secretion was also improved in gels containing collagen type IV or laminins [38]. Further, Yep, et al. showed that collagen IV-modified scaffolds could promote islet cell viability, decreased early-stage islet cell apoptosis, improved islet metabolic function and insulin release, and eventually restored euglycemia significantly faster [39]. The role of collagen based ECMs in support of islet viability and function was reviewed by Riopel and Wang and they concluded that embedding islets within a mixture of native ECM components that are commonly found in the pancreas is required to preserve islet cell survival and function [12]. In a separate strategy, synthetic peptide sequences have been identified and synthesized to imitate the effect of ECM proteins in stimulating the integrin receptors. In particular, Arginine-glycine-aspartic acid (RGD) peptide has been shown to reduce islet cell the apoptosis [33].

Our research group has developed a biocompatible 3D scaffold to improve islet cell viability and function in vitro and in vivo [40]. To keep the model as simple as possible, our matrix is composed of collagen type I and glycosaminoglycan. We then populated this scaffold with fibroblasts. While collagen provides a favourable initial ECM for islets, fibroblasts support and maintain the matrix integrity, produce other essential ECM components (e.g. Collagen IV, fibronectins, and laminins), and additionally support islets by producing various growth and angiogenic factors [41-44]. We found that a collagen gel that is seeded with dermal fibroblasts (known as Fibroblast Populated Collagen Matrix, FPCM) can function as a very favorable extracellular matrix for islet cells, resulting in significant preservation and improvement of islet cell viability and function $[40,45]$. Further, we showed that embedding islet within a FPCM significantly reduced the islet mass required for induction and maintenance of euglycemia in diabetic mice [40]. In another study, we demonstrated that FPCM enhanced survival and function of cultured human islets and reduced islet amyloid formation. Islet amyloid is formed by aggregation of islet amyloid polypeptide, which is secreted by islet PP cells. Islet amyloid plaques, which are a common pathological finding in type 2 diabetes, contribute to progressive $\beta$ cell dysfunction and death [46]. There is a growing body of evidence showing that toxic amyloid aggregates also form in cultured and transplanted human islets $[47,48]$. Consequently, with a similar mechanism seen in type 2 diabetes, amyloid formation results in accelerated $\beta$ cell dysfunction and apoptosis both in cultured and transplanted human islets, leading to early islet graft failure $[46,49,50]$. Our study showed that when human islets are embedded within a FPCM not only viability and function of islets were well preserved, islet amyloid formation and apoptosis was significantly reduced [51]. These studies collectively offer a new strategy to improve the viability of human islets, which can potentially improve the outcome of clinical islet transplantation.

\section{Conclusion}

ECM deprivation is a major cause of progressive islet cell dysfunction following islet isolation process, which consequently results in premature islet graft failure. Collagen based 3D matrices have been proven to significantly improve islet cell viability and function. Fibroblasts are the key role players in production and maintenance of ECM. They synthesize ECM elements including collagens, fibronectins, and other matrix components. As such, fibroblasts can provide an indispensable support for islets and maintain the integrity of the collagen-based matrices.

In summary, the body of evidence presented here strongly suggest that embedding islets within a collagen I matrix, particularly when populated with fibroblasts, significantly promotes islet cell viability and functionality, enhances engraftment of islet grafts, decreases the critical islet mass needed to treat diabetes in a murine islet transplantation model, and finally can prevent human islet amyloid deposition. These promising findings offer a valuable novel approach to reducing the number of islet donors per recipient and improving islet transplant outcome.

\section{Acknowledgments}

This work was supported by grants from the Canadian institutes of Health Research.

\section{Conflict of Interest}

The authors declare that there is no conflict of interest regarding the publication of this paper.

\section{References}

1. Ionescu-Tirgoviste C, Gagniuc PA, Gubceac E, Mardare L, Popescu I, et al. (2015) A 3D map of the islet routes throughout the healthy human pancreas. Sci Rep 5: 14634.

2. Shapiro AM, Pokrywczynska M, Ricordi C (2017) Clinical pancreatic islet transplantation. Nat Rev Endocrinol 13: 268-277.

3. Warnock GL, Liao YH, Wang X, Ou D, Ao Z, et al. (2007) An odyssey of islet transplantation for therapy of type 1 diabetes. World J Surg 31: 1569-1576.

4. Rickels MR, Peleckis AJ, Markmann E, Dalton-Bakes C, Kong SM, et al. (2016) Long-Term Improvement in Glucose Control and Counterregulation by Islet Transplantation for Type 1 Diabetes. J Clin Endocrinol Metab 101: 4421-4430.

5. Khosravi-Maharlooei M, Hajizadeh-Saffar E, Tahamtani $Y$, Basiri M, Montazeri L, et al. (2015) THERAPY OF ENDOCRINE DISEASE: Islet transplantation for type 1 diabetes: So close and yet so far away. Eur J Endocrinol 173: 165-183.

6. Bellin MD, Barton FB, Heitman A, Harmon JV, Kandaswamy $R$, et al. (2012) Potent induction immunotherapy promotes long-term insulin independence after islet transplantation in type 1 diabetes. Am J Transplant 12: 1576-1583.

7. Shapiro AM (2012) Islet transplantation in type 1 diabetes: Ongoing challenges, refined procedures, and long-term outcome. Rev Diabet Stud 9: 385-406. 
8. Frank AM, Barker CF, Markmann JF (2005) Comparison of whole organ pancreas and isolated islet transplantation for type 1 diabetes. Adv Surg 39: 137-163.

9. Davalli AM, Ogawa Y, Ricordi C, Scharp DW, Bonner-Weir $S$, et al. (1995) A selective decrease in the beta cell mass of human islets transplanted into diabetic nude mice. Transplantation 59: 817-820.

10. Biarnes M, Montolio M, Nacher V, Raurell M, Soler J, et al. (2002) Beta-cell death and mass in syngeneically transplanted islets exposed to short- and long-term hyperglycemia. Diabetes 51: 66-72.

11. Pileggi A, Ricordi C, Alessiani M, Inverardi L (2001) Factors influencing Islet of Langerhans graft function and monitoring. Clin Chim Acta 310: 3-16.

12. Riopel M, Wang R (2014) Collagen matrix support of pancreatic islet survival and function. Front Biosci (Landmark Ed) 19: 77-90.

13. Irving-Rodgers HF, Choong FJ, Hummitzsch K, Parish CR, Rodgers RJ, et al. (2014) Pancreatic islet basement membrane loss and remodeling after mouse islet isolation and transplantation: Impact for allograft rejection. Cell Transplant 23: 59-72.

14. Wang RN, Rosenberg L (1999) Maintenance of beta-cell function and survival following islet isolation requires re-establishment of the islet-matrix relationship. J Endocrinol 163: 181-190.

15. Cabrera O, Berman DM, Kenyon NS, Ricordi C, Berggren $\mathrm{PO}$, et al. (2006) The unique cytoarchitecture of human pancreatic islets has implications for islet cell function. Proc Natl Acad Sci U S A 103: 2334-2339.

16. Bosman FT, Stamenkovic I (2003) Functional structure and composition of the extracellular matrix. J Pathol 200: 423-428.

17. Kular JK, Basu S, Sharma RI (2014) The extracellular matrix: Structure, composition, age-related differences, tools for analysis and applications for tissue engineering. $\mathrm{J}$ Tissue Eng 5: 2041731414557112.

18. Tanzer ML (2006) Current concepts of extracellular matrix. J Orthop Sci 11: 326-331.

19. Gordon MK, Hahn RA (2010) Collagens. Cell Tissue Res 339: 247-257.

20. Eckes B, Nischt R, Krieg T (2010) Cell-matrix interactions in dermal repair and scarring. Fibrogenesis Tissue Repair 3: 4.

21. Edamura K, Nasu K, Iwami Y, Ogawa H, Sasaki N, et al. (2003) Effect of adhesion or collagen molecules on cell attachment, insulin secretion, and glucose responsiveness in the cultured adult porcine endocrine pancreas: A preliminary study. Cell Transplant 12: 439-446.

22. Kaido T, Perez B, Yebra M, Hill J, Cirulli V, et al. (2004) Alphav-integrin utilization in human beta-cell adhesion, spreading, and motility. J Biol Chem 279: 17731-17737.

23. Nagata N, Gu Y, Hori H, Balamurugan AN, Touma M, et al. (2001) Evaluation of insulin secretion of isolated rat islets cultured in extracellular matrix. Cell Transplant 10: 447-451.

24. Wang R, Li J, Rosenberg L (2001) Factors mediating the transdifferentiation of islets of Langerhans to duct epithelial-like structures. J Endocrinol 171: 309-318.

25. Hynes RO (2002) Integrins: Bidirectional, allosteric signaling machines. Cell 110: 673-687.

26. Ris F, Hammar E, Bosco D, Pilloud C, Maedler K, et al. (2002) Impact of integrin-matrix matching and inhibition of apoptosis on the survival of purified human beta-cells in vitro. Diabetologia 45: 841-850.
27. Kaido T, Yebra M, Cirulli V, Montgomery AM (2004) Regulation of human beta-cell adhesion, motility, and insulin secretion by collagen IV and its receptor alpha1beta1. J Biol Chem 279: 53762-53769.

28. Valiathan RR, Marco M, Leitinger B, Kleer CG, Fridman R (2012) Discoidin domain receptor tyrosine kinases: New players in cancer progression. Cancer Metastasis Rev 31: 295-321.

29. Leitinger B (2003) Molecular analysis of collagen binding by the human discoidin domain receptors, DDR1 and DDR2. Identification of collagen binding sites in DDR2. J Biol Chem 278: 16761-16769.

30. Vogel WF, Abdulhussein R, Ford CE (2006) Sensing extracellular matrix: An update on discoidin domain receptor function. Cell Signal 18: 1108-1116.

31. Krishnamurthy M, Li J, Fellows GF, Rosenberg L, Goodyer CG, et al. (2011) Integrin \{alpha\}3, but not \{beta\}1, regulates islet cell survival and function via PI3K/Akt signaling pathways. Endocrinology 152: 424-435.

32. Saleem S, Li J, Yee SP, Fellows GF, Goodyer CG, et al. (2009) Beta1 integrin/FAK/ERK signalling pathway is essential for human fetal islet cell differentiation and survival. J Pathol 219: 182-192.

33. Pinkse GG, Bouwman WP, Jiawan-Lalai R, Terpstra OT, Bruijn JA, et al. (2006) Integrin signaling via RGD peptides and anti-beta1 antibodies confers resistance to apoptosis in islets of Langerhans. Diabetes 55: 312-317.

34. Frisch SM, Francis H (1994) Disruption of epithelial cell-matrix interactions induces apoptosis. J Cell Biol 124: 619-626.

35. Gibly RF, Graham JG, Luo X, Lowe WL Jr, Hering BJ, et al. (2011) Advancing islet transplantation: From engraftment to the immune response. Diabetologia 54: 2494-2505.

36. Thomas F, Wu J, Contreras JL, Smyth C, Bilbao G, et al. (2001) A tripartite anoikis-like mechanism causes early isolated islet apoptosis. Surgery 130: 333-338.

37. Thomas FT, Contreras JL, Bilbao G, Ricordi C, Curiel D, et al. (1999) Anoikis, extracellular matrix, and apoptosis factors in isolated cell transplantation. Surgery 126: 299-304.

38. Weber LM, Hayda KN, Anseth KS (2008) Cell-matrix interactions improve beta-cell survival and insulin secretion in three-dimensional culture. Tissue Eng Part A 14: 1959-1968.

39. Yap WT, Salvay DM, Silliman MA, Zhang X, Bannon ZG, et al. (2013) Collagen IV-modified scaffolds improve islet survival and function and reduce time to euglycemia. Tissue Eng Part A 19: 2361-2372.

40. Jalili RB, Moeen Rezakhanlou A, Hosseini-Tabatabaei A, Ao Z, Warnock GL, et al. (2011) Fibroblast populated collagen matrix promotes islet survival and reduces the number of islets required for diabetes reversal. J Cell Physiol 226: 1813-1819.

41. Rabinovitch A, Russell T, Mintz DH (1979) Factors from fibroblasts promote pancreatic islet $B$ cell survival in tissue culture. Diabetes 28: 1108-1113.

42. Iyer VR, Eisen MB, Ross DT, Schuler G, Moore T, et al. (1999) The transcriptional program in the response of human fibroblasts to serum. Science 283: 83-87.

43. Miki A, Narushima M, Okitsu T, Takeno $Y$, Soto-Gutierrez A, et al. (2006) Maintenance of mouse, rat, and pig pancreatic islet functions by coculture with human islet-derived fibroblasts. Cell Transplant 15: 325-334.

44. Liu H, Chen B, Lilly B (2008) Fibroblasts potentiate blood vessel formation partially through secreted factor TIMP-1. Angiogenesis 11: 223-234. 
45. Hosseini-Tabatabaei A, Jalili RB, Hartwell R, Salimi S, Kilani RT, et al. (2013) Embedding islet in a liquid scaffold increases islet viability and function. Can J Diabetes 37: 27-35.

46. Westermark GT, Westermark P (2013) Islet amyloid polypeptide and diabetes. Curr Protein Pept Sci 14: 330-337.

47. Marzban L, Tomas A, Becker TC, Rosenberg L, Oberholzer $\mathrm{J}$, et al. (2008) Small interfering RNA-mediated suppression of proislet amyloid polypeptide expression inhibits islet amyloid formation and enhances survival of human islets in culture. Diabetes 57: 3045-3055.

48. Potter KJ, Abedini A, Marek P, Klimek AM, Butterworth S, et al. (2010) Islet amyloid deposition limits the viability of human islet grafts but not porcine islet grafts. Proc Natl Acad Sci U S A 107: 4305-4310.

49. Westermark P, Andersson A, Westermark GT (2011) Islet amyloid polypeptide, islet amyloid, and diabetes mellitus. Physiol Rev 91: 795-826.

50. Westermark GT, Davalli AM, Secchi A, Folli F, Kin T, et al. (2012) Further evidence for amyloid deposition in clinical pancreatic islet grafts. Transplantation 93: 219-223.

51. Zhang Y, Jalili RB, Warnock GL, Ao Z, Marzban L, et al. (2012) Three-dimensional scaffolds reduce islet amyloid formation and enhance survival and function of cultured human islets. Am J Pathol 181: 1296-1305. 